\title{
Methods for estimating decapod larval supply and settlement: importance of larval behavior and development stage
}

\author{
Per-Olav Moksnes*, Håkan Wennhage \\ Göteborg University, Kristineberg Marine Research Station, 45034 Fiskebäckskil, Sweden
}

\begin{abstract}
In marine benthic organisms with a pelagic larval phase, assessment of recruitment regulation necessitates accurate estimates of larval supply and initial settlement densities. We assessed 2 commonly used methods for estimating decapod larval supply, plankton net tows and artificial settlement substrates (ASS), together with a new technique using passive-migration traps. The aim was to evaluate how these methods estimate larval supply and settlement of 3 common decapod species (the shore crab Carcinus maenas L., the brown shrimp Crangon crangon L. and the grass shrimps Palaemon spp.) in a microtidal nursery area on the Swedish west coast, and to assess how these estimates relate to the juvenile recruitment of these species. Discrete plankton net tows outside the shallow nursery area collected a higher proportion of larvae at an early development stage, compared to the other methods, and produced only a snapshot of the variable water-column abundance of shore crab and grass shrimp larvae that correlated poorly with numbers collected with ASS at the same location. Artificial settlement substrates appeared to produce good, integrated relative estimates of shore crab larval supply and settlement. The number of larvae collected from ASS correlated significantly with larval abundance estimated by passive-migration traps in shallow nursery areas, and reflected changes in shore crab settlement densities in caged mussel habitats. We did not detect any effect of predation on ASS placed in nursery areas. However, a large proportion (an estimated $83 \%$ ) of shore crab postlarvae appeared to emigrate from ASS immersed for periods longer than $12 \mathrm{~h}$, possibly during the night. All grass shrimp larvae appeared to emigrate from the collectors within $24 \mathrm{~h}$, suggesting that ASS immersed longer than $12 \mathrm{~h}$ do not produce useful integrated estimates of larval supply for this species. These results demonstrate the importance of assessing postlarval emigration patterns from ASS to optimize immersion and collection time, and to avoid confounded estimates of larval abundance and settlement. A new method using replicated passive migration traps that fished continuously in opposite directions (on-shore and off-shore) gave promising integrated estimates of net fluxes (total number immigrating minus number emigrating per unit time) of both pelagic postlarvae and early benthic juvenile stages of crabs and shrimp. The majority of the brown shrimp recruits were young juveniles, demonstrating the importance of incorporating juvenile migration in recruitment studies of motile benthic species. High numbers of shore crab and grass shrimp larvae were found to emigrate from the bay, indicating that many decapod postlarvae found in nursery areas may be transitional. The emigrating larvae were on average in an earlier development stage than those migrating to the bay. These short-term experiments demonstrate the importance of assessing larval development stage and migratory behavior when estimating larval supply and settlement for recruitment studies.
\end{abstract}

KEY WORDS: Larval supply $\cdot$ Settlement $\cdot$ Juvenile migration $\cdot$ Development stage $\cdot$ Sampling problems Resale or republication not permitted without written consent of the publisher

\section{INTRODUCTION}

The relative importance of pre- and post-settlement processes for population regulation in benthic organ-

*E-mail: p.moksnes@kmf.gu.se isms is presently a major focus in marine ecology (Caley et al. 1996). To assess settler-recruit relationships or density-dependent post-settlement mortality in a population, it is imperative to obtain an accurate estimate of initial settlement densities. In nature this is very difficult to measure, because larvae are com-

(C) Inter-Research 2001 
monly small and cryptic, and also because mortality can occur during settlement.

One way to overcome these difficulties is to measure the abundance of postlarvae in the water column above the benthic population as a substitute for settlement densities. However, recent studies imply that discrete estimates of larval abundance in the water column, collected with plankton nets or pumps (the traditional methods) fail to take into account the high spatio-temporal variability in larval abundance and flow velocity (Gaines \& Bertness 1993) and behavioral aspects of the larvae (Miron et al. 1995), and therefore pose a serious impediment to progress in this field. Moreover, postlarval densities in the water may not reflect settlement densities if the larvae are not competent to settle. Quantitative measurements of postlarval development state may therefore be necessary to relate planktonic availability with settlement patterns (Lipcius et al. 1990).

An alternative method for estimating larval supply and settlement densities is to measure larval and juvenile abundance on artificial substrata where mortality is thought to be low. Artificial settlement substrates (ASS) or collectors that sample passively over an immersion period have been used for over 20 yr to estimate larval abundance and settlement in decapod species (i.e. the western rock lobster Panulirus longipes cygnus [Phillips 1972], the grapsid crab Pachygrapsus crassipes [Shanks 1983], the rock crab Cancer irrotatus [Beniger et al. 1986], the blue crab Callinectes sapidus [Goodrich et al. 1989, van Montfrans et al. 1990], the red king crab Paralithodes camtschaticus [Blau \& Byersdorfer 1994], and the Dungeness crab Cancer magister [Eggleston \& Armstrong 1995]). This method was recently standardized to quantify daily settlement patterns of blue crab postlarvae over an extensive geographical area covering both the Atlantic and the Gulf coasts of the USA (van Montfrans et al. 1995 and references therein). The ASS method makes use of the thigmotactic behavior of many decapod postlarvae to cling to encountered objects (Goodrich et al. 1989), and therefore integrates larval behavior and abundance in a relative measurement of larval supply. In comparison with postlarvae collected with plankton nets, ASS catch a higher proportion of postlarvae in a late developmental stage (i.e. in premolt; Lipcius et al. 1990), and may therefore give better estimates of settlement densities. Since this technique samples continuously, temporal variation in larval abundance and flow velocity are of lesser concern.

One potential problem with passive collectors is that postlarval densities on ASS will not reflect settlement densities if larvae that are not competent to settle also cling to the collectors. If many larvae cling only temporarily to the ASS, estimates of larval abundance may also be confounded, since the rate of emigration may vary in time and space as a result of light conditions, tidal phase, or larval density on the collector. The possibility that the ASS may only be a transitional substrata for postlarvae has rarely been reflected upon in earlier studies (but see Goodrich et al. 1989, Olmi et al. 1990) and has, to our knowledge, never been investigated. Similarly, the potential problem of variable predation on collectors has been little discussed and, as far as we know, never been assessed.

In motile species, post-settlement dispersal by juveniles may also contribute to the juvenile recruitment of local populations (see Palmer et al. 1996 for review). If a large proportion of the recruitment occurs through juvenile migration, estimates of larval supply and settlement densities alone will not suffice to assess recruitment regulation. Therefore, it is important to understand the significance of post-settlement migration when using estimates of settlement in recruitment studies. Still, juvenile migration is rarely incorporated into studies of recruitment regulation, and there is a general lack of methods that quantitatively assess this process.

This study, based on 3 short field experiments, assessed 3 different methods for estimating larval supply and settlement in decapod species: (1) plankton net tows, (2) artificial settlement substrates, and (3) a new method using passive-migration traps to estimate fluxes of both pelagic larvae and benthic juveniles to shallow nursery areas. The aim was to evaluate each sampling method to be used in recruitment studies of 3 decapod species (the shore crab Carcinus maenas L., the brown shrimp Crangon crangon L. and the grass shrimps Palaemon adspersus and P. elegans Rathke). Specifically, the aim was to assess how different relative estimates of larval supply and settlement were affected by temporal variation in larval abundance and flow velocities, development stage of the larvae, migratory behavior of the larvae, and predation. A final goal was to assess the importance of post-settlement migration for juvenile recruitment in order to evaluate if this process needs to also be incorporated in recruitment studies of these species.

\section{MATERIALS AND METHODS}

Three field experiments were conducted during the summer of 1995 and 1996 in the Gullmarsfjord area on the Swedish west coast $\left(58^{\circ} 15^{\prime} \mathrm{N}, 11^{\circ} 27^{\prime} \mathrm{E}\right)$, which has a small tidal amplitude of less than $30 \mathrm{~cm}$. During the summer and fall months, high densities of postlarvae and juveniles of shore crab Carcinus maenas, brown shrimp Crangon crangon and grass shrimps Palaemon spp. are found in shallow, soft sediment $(<1 \mathrm{~m})$ bays. In 
Fig. 1. (a) Location of Gullmarsfjord (western Sweden) and Bökevik, where the experiments were carried out. (b) Schematic drawing of topography of Bökevik (seen from above) and the location of the different sampling gear used in Expt 3 (see 'Materials and methods' for details)

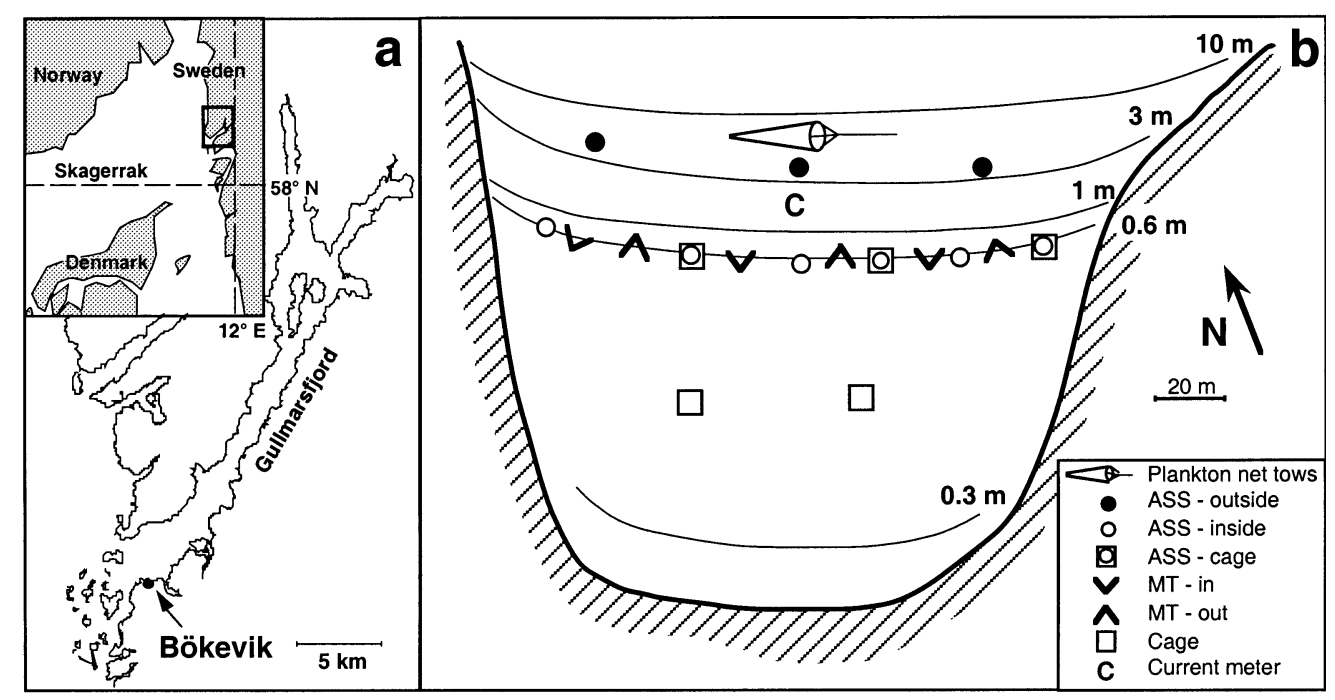

the Gullmarsfjord area, the bays are small in size ( 1 to $4 \mathrm{ha}$ ), they fall steeply into the fjord (30 to $100 \mathrm{~m}$ deep), and are surrounded by extensive areas of steep rocky coastline, making each bay a well-defined, potentially isolated nursery area with excellent conditions for obtaining estimates of larval fluxes and settlement. The water exchange in these shallow bays is driven mainly by density differences (baroclinic circulation), wind, and large-scale currents along shore, whereas tides are thought to play a negligible role (Andersson \& Rahm 1985, Söderkvist 1997). All experiments were carried out in Bökevik (Fig. 1), a semi-exposed, small (2.4 ha) and shallow (mean depth: $0.4 \mathrm{~m}$ ) bay with sandy sediment and a mosaic of small patches (0.1 to $10 \mathrm{~m}^{2}$ ) of the blue mussel Mytilus edulis L. and eelgrass Zostera marina L. covering approximately $30 \%$ of the bottom area.

Expt 1. ASS - effect of immersion time. A $4 \mathrm{~d}$ field experiment was conducted in Bökevik in August 1995 to assess how different immersion times of artificial settlement substrates ASS affected the total number of shore crab settlers (postlarvae and metamorphosed benthic stages) and shrimp larvae collected after the same period of time. This experiment would test if losses (emigration or predation) on the ASS were significant and constant over time. The ASS were standardized cylindrical collectors (van Montfrans et al. 1995) consisting of 'hogs-hair' air-conditioning filter material wrapped around a floating PVC-pipe. Four different immersion times were assessed: 12, 24, 48 and $96 \mathrm{~h}$. One ASS for each immersion time was individually placed approximately $2 \mathrm{~m}$ apart in a group. Three groups, placed approximately $25 \mathrm{~m}$ apart were used concurrently $(n=3)$. Treatments were randomly assigned within groups. The ASS were floating just below the surface at the opening of the bay, approxi- mately $3 \mathrm{~m}$ above the bottom where they were anchored. The $12 \mathrm{~h}$ ASS were replaced between 08:00 and 09:00 $\mathrm{h}$ in the morning and at 20:00 and 21:00 $\mathrm{h}$ in the evening (during daylight at this latitude). The other time-treatments were replaced at the same time in the morning on appropriate days. The ASS were retrieved by boat, carefully placed in 301 buckets, and soaked for a minimum of $30 \mathrm{~min}$ in fresh water before being rinsed into a $750 \mu \mathrm{m}$ sieve, after which postlarvae were identified and enumerated alive.

To identify a critical immersion time, or time of day, after which losses occur, and to see how different immersion times reflected variation in larval abundance, several analyses were made that tested if the number of settlers collected on the ASS differed between day and night, and if the total number of settlers differed between different immersion times after different periods of time. When we compared different immersion times, the number of settlers collected on individual ASS of shorter immersion times was added over the total time period being assessed, and the sum was used as a replicate in the analyses. The number of shore crab Carcinus maenas settlers and grass shrimp larvae Palaemon spp. per ASS were tested separately in 4 different ANOVA models using: (1) number of larvae on $12 \mathrm{~h}$ ASS as the dependent variable and time of day (day and night) and day (1 to 4) as independent variables; (2) the sum of larvae found on each $12 \mathrm{~h}$ ASS over $24 \mathrm{~h}$ and the number of larvae on the $24 \mathrm{~h}$ ASS as the dependent variable, and time-treatment (12 and $24 \mathrm{~h}$ ) and day (1 to 4) as independent variables; (3) the sum of larvae found on 12 and $24 \mathrm{~h}$ ASS over $48 \mathrm{~h}$ and on the $48 \mathrm{~h}$ ASS as the dependent variable, and timetreatment (12 to $48 \mathrm{~h}$ ) and day (1 to 2 and 3 to 4 ) as independent variables; (4) the sum of larvae found on 12, 24 and $48 \mathrm{~h}$ ASS over $96 \mathrm{~h}$ and on the $96 \mathrm{~h}$ ASS as 
dependent variables, and time-treatment (12 to $96 \mathrm{~h}$ ) as the independent variable. In a complementary analysis, the proportion of first instar shore crabs was analyzed using the last ANOVA model. Before the
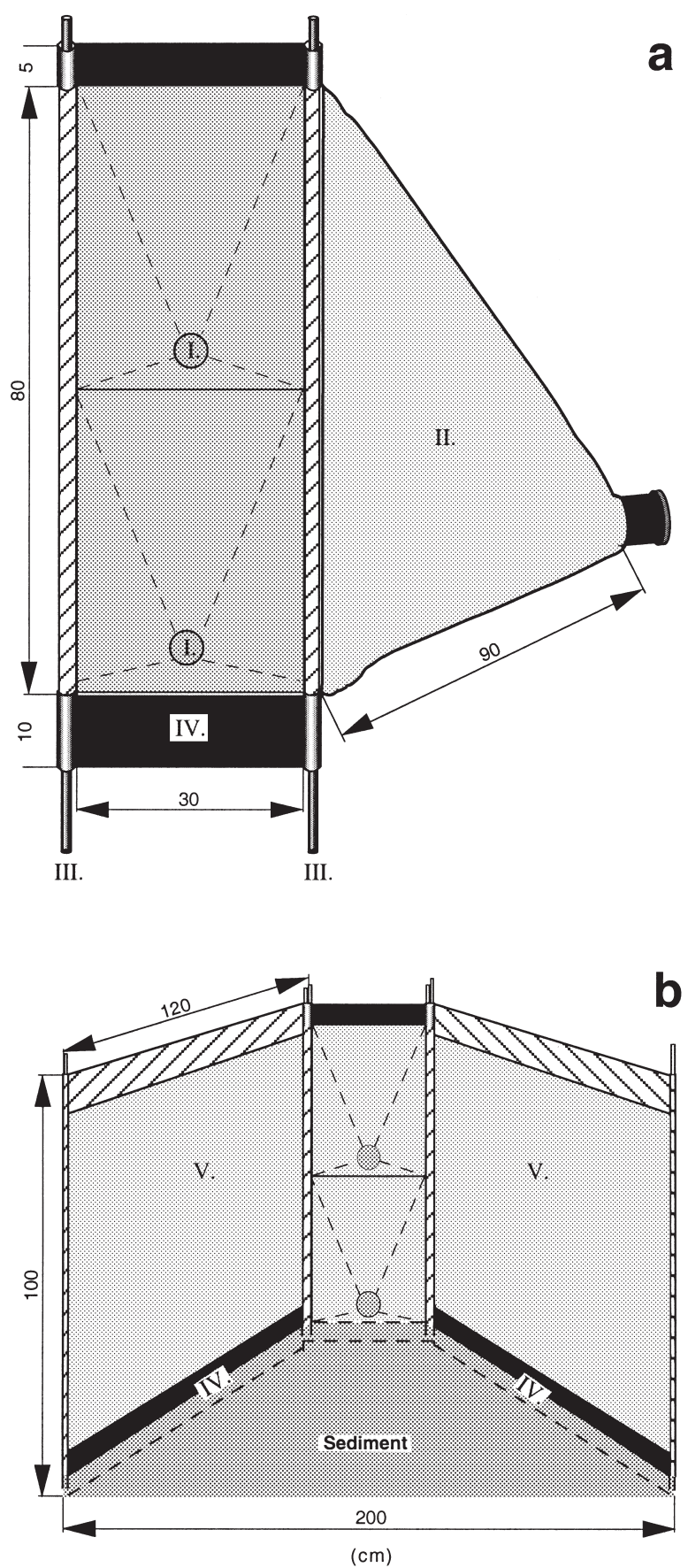

Fig. 2. Benthic-pelagic migration trap (MT). (a) Front view of MT showing the trap consisting of 2 conical openings (I) that enter into a plankton net (II), aluminum rods (III) and sheets (IV) anchor the trap to the sediment ('arms' and the anti-predation net is not shown); (b) front view of the MT with the detachable 'arms' (V) as applied in the field (see 'Materials and methods' for details)
ANOVA was performed, all data were tested for homoscedasticity with Cochran's $C$-test (Sokal \& Rohlf 1981) and transformed only if found to be heteroscedastic. A posteriori multiple-comparison tests were carried out with the Student-Newman-Keuls (SNK) procedure.

Expt 2. Benthic-pelagic migration trap-a pilot study. A new method, a benthic-pelagic migration trap (MT), was developed to estimate larval and juvenile fluxes of decapods. The aim was to develop a method that did not have the shortcomings of the discrete samples produced by plankton nets, that was less sensitive to emigration and predation than the ASS (see 'Results'), and that could be used in a microtidal system where low current conditions necessitate long sampling times. A further goal was to develop a technique that could produce quantitative estimates of both larval and juvenile fluxes to shallow soft-bottom areas for the assessment of juvenile recruitment.

The MT technique used replicated traps that fished continuously from the bottom to the surface in opposite directions, either facing onshore or offshore. The trap consisted of a conical plankton net $(600 \mu \mathrm{m})$ with a rectangular $(30 \times 80 \mathrm{~cm})$ opening (Fig. 2a). The opening was fitted with 2 smaller conical plankton nets with a small ( $7 \mathrm{~cm}$ diameter) exit into the larger net to prevent captured animals from escaping: a lower net for epibenthic animals, and a higher net for planktonic animals (Fig. 2a). The higher opening was placed just below the water surface at mean low water level. Two detachable 'arms' of plankton-net cloth $(800 \mu \mathrm{m} ; 120 \times$ $100 \mathrm{~cm}$ ) were attached at a $45^{\circ}$ angle, with an opening between the arms of approximately $2.0 \mathrm{~m}$ (Fig. 2b). The bottom of the trap and arms were fitted with aluminum sheets that were pushed into the sediment. Aluminum rods with strings splayed from their top ends were used as a net frame and for stability. The cod end of the trap was tethered behind the trap to maintain a constant profile of the net. A replaceable $2 \mathrm{~mm}$-mesh net was attached to the opening of the plankton net to prevent predators from entering. The MTs were positioned at approximately $0.6 \mathrm{~m}$ depth (at mean water level) at the opening of the shallow-bay study site (Fig. 1b). Because of the small tidal amplitude in this area, the trap did not get submerged during high tide and it continuously fished a section of the whole water column from the bottom to the surface during a $24 \mathrm{~h}$ immersion.

This technique was initially tested for $11 \mathrm{~d}$ in July 1996 in Bökevik to assess how the traps performed during different hydrodynamic conditions and to test if the method could produce estimates of sufficiently high precision to detect differences between days and fishing directions. This pilot study would also allow us to investigate the relative importance of post-settle- 
ment dispersal for juvenile recruitment to a shallow nursery area in the 3 assessed species. We used $4 \mathrm{MTs}$, 2 facing onshore (MT-in) and 2 facing offshore (MTout; $\mathrm{n}=2$ ), randomly positioned along a $0.6 \mathrm{~m}$ transect at the opening of the bay (Fig. 1b). Thus, the MTs estimated the flux of recruits to the shallow area of the bay inside the transect. Benthic field samples showed that the deeper outer part of the bay had very low densities of decapod larvae and young juveniles and is probably used little as a settlement area for the investigated species (P.-O.M. unpubl. data). The traps were emptied and randomly relocated daily between 14:00 and 16:00 $\mathrm{h}$ for a total of $11 \mathrm{~d}$. Decapod postlarvae were sorted and enumerated alive. The carapace length (CL) of brown shrimp was measured using a dissecting microscope fitted with an ocular micrometer. To test for net fluxes of larvae over the examined period, the number of shore crab megalopae and brown shrimp [both $\log (x+1)$-transformed] were used as the dependent variables in 2 separate 2- factor ANOVA models with direction (in and out) and date as the independent variables. The number of grass shrimp larvae was too low to be assessed during this period.

Expt 3. Assessment of 3 methods for estimating decapod larval supply and settlement. Larval supply: A $6 \mathrm{~d}$ field experiment was conducted in Bökevik at the beginning of August 1996 to assess different techniques for measuring larval supply and settlement of decapod crustaceans. Six different treatments were assessed concurrently (Fig. 1b). (1) Plankton net tows: a circular plankton net (200 $\mu \mathrm{m}$ mesh; $0.5 \mathrm{~m}^{2}$ opening) fitted with a mechanical flowmeter and towed at the surface from a boat across the opening of the bay (approximately $200 \mathrm{~m}, 6$ to $8 \mathrm{~min}$ duration, sampling approximately $100 \mathrm{~m}^{3}$ of water) above 3 to $5 \mathrm{~m}$ depth; the plankton net catches were standardized to number of larvae $100 \mathrm{~m}^{-3}$ using the flowmeter. (2) ASS-outside: ASS floating at the surface at the opening of the bay above approximately $3 \mathrm{~m}$ depth and approximately $40 \mathrm{~m}$ from the sampling gear located inside the bay (Fig. 1b). (3) ASS-inside: ASS floating at the surface at approximately $0.6 \mathrm{~m}$ depth inside the bay. (4) ASScage: ASS floating at the surface at approximately $0.6 \mathrm{~m}$ depth placed inside a $2 \mathrm{~mm}$-mesh cage $(1.0 \times 0.5$ $\times 1.0 \mathrm{~m}$ ) without a top. (5) MT-in; MTs located at approximately $0.6 \mathrm{~m}$ depth inside the bay facing offshore. (6) MT-out; MTs facing onshore. Three replicates of each treatment were used each day during the $6 \mathrm{~d}$ experiment, and all equipment was randomly relocated along the $0.6 \mathrm{~m}$ depth profile each day. The ASS and MT were exchanged between 14:00 and 18:00 h, and the plankton tows were performed between 18:00 and 19:00 h each day. The ASS were sampled as described in Expt 1. All animals were sorted and enumerated alive. Subsamples were preserved in alcohol and analyzed later to determine species and larval stage of the grass shrimps, and carapace length of the brown shrimp, using a dissecting microscope fitted with an ocular micrometer. A large proportion of the grass shrimp larvae was found to be in Larval Stage V, which precedes the postlarval stage. Since there is no proper taxonomic characteristic that allows one to separate alcohol-preserved specimens of Stage V larvae of Palaemon elegans and P. adspersus (Höglund 1943), all larvae from these 2 species were pooled and analyzed as Palaemon spp. Since plankton net tows were not possible inside the shallow bay, the ASS-outside provided a comparison of the 2 methods (ASS-outside vs plankton tows) at the same location. Comparisons between ASS-outside and -inside identified how well measurements of larvae just outside the bay reflected what actually entered the bay. The ASS-cage treatment assessed the impact of predation when compared to ASS-inside the bay.

The number of shore crabs (megalopae and first instars) and grass shrimp larvae [both $\log (x+1)$-transformed] were used as dependent variables in a series of analyses to test how the different methods estimated the larval supply of these 2 species. Correlation analyses were performed between ASS-outside and plankton net tows, ASS-outside and ASS-inside, ASS-inside and ASS-cage, and MT-in and ASS-inside. The ASSoutside and plankton net data were also tested separately in two 1-way ANOVA models, using date as the independent variable, to assess if the precision in the 2 methods was high enough to detect differences between days. The effect of predation on ASS-inside the bay was also tested in a 2-factor ANOVA-model with treatment (cage, no cage) and date as independent variables. To test for net-fluxes of larvae and juveniles measured in the migration traps over the examined period, the number of shore crabs, grass shrimp and brown shrimp [all $\log (x+1)$-transformed] were used as dependent variables in 3 separate 2-factor ANOVA-models, with direction (in and out) and date as the independent variables.

Developmental stage: To assess if the developmental stage differed in shore crab and grass shrimp larvae collected with the different methods, the proportion of first instar shore crabs (number first instars/total number; square-root-transformed) and the proportion postlarvae of grass shrimp (no. postlarvae/no. postlarvae + no. Stage V larva) were tested as dependent variables in 2 separate 2-factor ANOVA models with method (plankton net tows, ASS-inside, ASS-outside, ASScage, MT-in and MT-out) and date as independent variables. Grass shrimp data remained heteroscedastic despite transformations, and the null hypothesis was therefore rejected at an alpha level lower than the $\mathrm{p}$ value of the Cochran's C-test (Underwood 1981). 
Date was not included as a factor in this model since subsamples for analysis of larval stages had been pooled within each date.

As a complement to this analysis, metamorphosis rate of shore crab megalopae collected with the different methods was measured in the laboratory. Twenty megalopae were taken from each sampling method on 3 different days when sufficiently high numbers were collected with all methods, and were put in two 0.51 cups (10 in each). On a daily basis they were fed Artemia sp. nauplii, the water was changed, and all first-instar crabs were removed, until all megalopae had metamorphosed. The average number of days to metamorphosis per cup was used as the dependent variable in a 2-factor ANOVA model with method (plankton net tows, ASS-inside, ASS-outside, MT-in and MT-out) and date as independent variables. To examine if the metamorphosis rate of the megalopae collected on ASS, had been affected by the 30 to 60 min freshwater wash, a preliminary experiment was performed. Megalopae were left for $60 \mathrm{~min}$ in freshwater and then monitored for metamorphosis as described above. A control treatment was left in saltwater for the same period of time. Five replicates of each treatment were analyzed in a 1-factor ANOVA-model using time to metamorphosis (TTM) as the dependent variable. No significant difference was found in TTM between megalopae subjected to a freshwater wash $(2.2 \mathrm{~d})$ and the control treatment $(2.3 \mathrm{~d}$; ANOVA: $F=$ 0.15 , $\mathrm{df}=1,8, \mathrm{p}=0.71$ ), indicating that megalopae from the ASS could be compared with postlarvae collected with MT and plankton nets.

Settlement: To assess settlement of shore crab megalopae in natural habitats, excluding the effect of predation, 2 cages $(2 \mathrm{~mm}$ mesh, $1.0 \times 0.5 \times 1.0 \mathrm{~m}$, no top) were located inside the bay at the beginning of the experiment (Fig. 1b) and provided with 40 live adult blue mussels (preferred settlement habitat; Hedvall et al. 1998). The cages were sampled after $48 \mathrm{~h}$, after which 40 new mussels were placed inside the cages, which were sampled again after another $48 \mathrm{~h}$ period. This supplementary treatment allowed us to test if the different estimates of variation in larval supply were reflected in the settlement patterns in natural habitats. The $\log (x+1)$-transformed number of megalopae and first-instar crabs accumulated over $48 \mathrm{~h}$ was used as the dependent variable and method (cage with mussels, ASS-outside, ASS-inside, ASS-cage, MT-in) and date were used as the independent variables in a 2-factor ANOVA-model. Only the methods providing continuous measurements of larvae were used in this test to obtain the same unit in the dependent variable (no. of settlers $48 \mathrm{~h}^{-1}$ ).

Wind velocities, tidal amplitude, water temperature and salinity were constantly measured at Kristineberg
Marine Research Station next to the bay. Current velocities were measured from July 17 to August 5, 1996 using an acoustic current meter (3-D ACM, Falmouth Scientific Inc., Cataumet, MA, USA) that was placed at $1 \mathrm{~m}$ depth (at mean water level), 2 to $3 \mathrm{~m}$ above the bottom, inbetween the ASS-outside and -inside (Fig. 1b). Data of current direction inside the bay were taken twice a day (morning and afternoon) from drift markers floating just below the surface and constantly moored at 6 locations inside the bay during Expts 2 and 3. Occasional current measurements were also taken using passively floating markers that floated just below the surface.

\section{RESULTS}

\section{Expt 1. Artificial settlement substrates - effect of immersion time}

Shore crabs Carcinus maenas

Losses of larvae from the ASS were not constant over time, and an increased immersion time resulted in an increased loss of settlers (megalopae and first-instar crabs), although the proportion of metamorphosed crabs increased (Fig. 3). No consistent difference between day and night (approximately $6 \mathrm{~h}$ darkness) immersion was found (Fig. 3a). Significantly higher numbers of settlers were found during the day than at night for Day 1, whereas no day/night differences were detected throughout the following days, resulting in a significant interaction effect (ANOVA; $F=6.6$, df = $3,16, \mathrm{p}<0.01$; SNK test, $\mathrm{p}<0.05$; Fig. 3a). The number of settlers on the $24 \mathrm{~h}$ ASS was significantly lower than the sum of settlers collected from the $12 \mathrm{~h}$ ASS over $24 \mathrm{~h}$ on all days (Table 1 ; Fig. 3b). The proportional difference in settlers collected for the 2 immersion periods was similar on all days (40 to $60 \%$ ), and a significant increase from the first $2 \mathrm{~d}$ to the final days were found with both immersion times (SNK test, $\mathrm{p}<0.05$ ). The log-transformed number of settlers on the $48 \mathrm{~h}$ ASS was significantly lower than the sum of settlers on the 12 and $24 \mathrm{~h} \mathrm{ASS}$ during both halves of the experiment, but also showed a significant increase from Days 2 to 4 (Table 1; SNK test, $\mathrm{p}<0.05$; Fig 3c). The sum of settlers over $96 \mathrm{~h}$ was significantly higher on the $12 \mathrm{~h}$ ASS (238 crabs) compared to the longer immersion times (24 h: 127 crabs; 48 h: 83 crabs; 96 h: 80 crabs) which did not differ significantly from each other (ANOVA: $F=23.0, \mathrm{df}=3,8, \mathrm{p}<0.001$; SNK test, $\mathrm{p}<0.05$; Fig. 3d). The proportion of first-instar crabs increased significantly from the 12 and $24 \mathrm{~h}$ ASS (2 to $6 \%$ ) to the $48 \mathrm{~h}$ $\operatorname{ASS}(27 \%)$ and to the $96 \mathrm{~h}$ ASS $(52 \%$; ANOVA; $F=$ 72.4, df =3,8, p < 0.0001; SNK test, p < 0.05; Fig. 3d). 

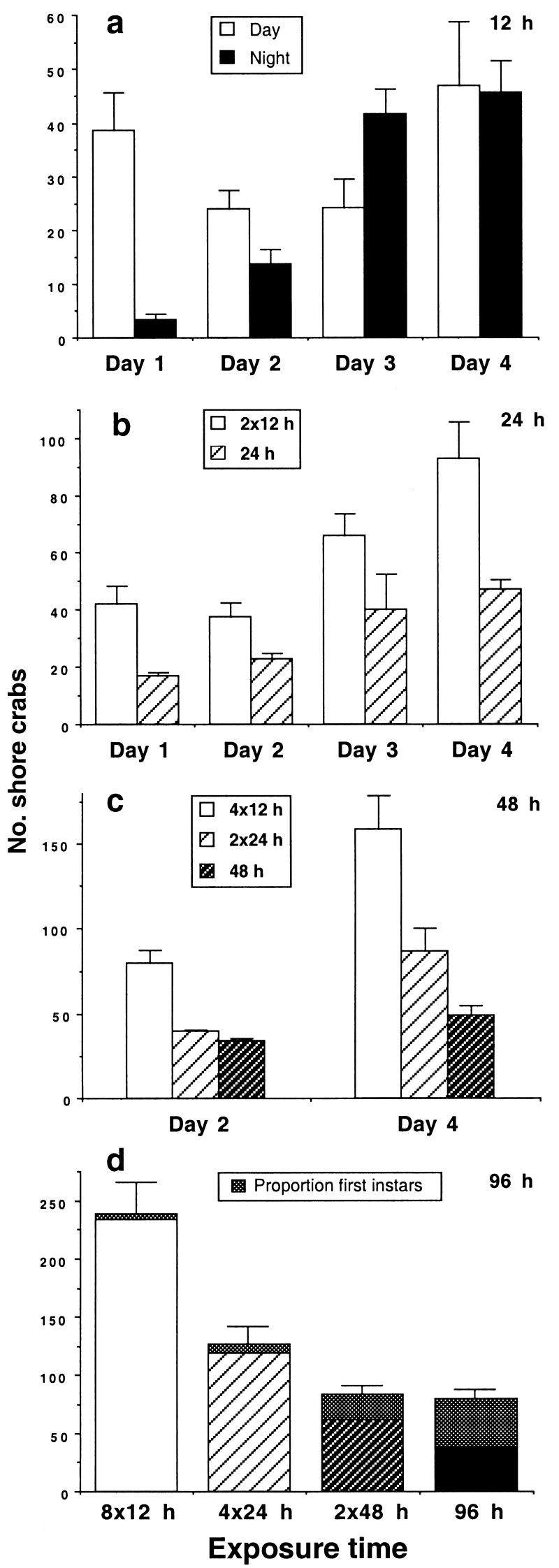

Grass shrimp Palaemon spp.

Losses of grass shrimp larvae from ASS increased with increasing immersion time, and most larvae appeared to remain for less than $24 \mathrm{~h}$ on the collectors (Fig. 4). For the $12 \mathrm{~h}$ immersion time, significantly higher numbers of larvae were found in the night samples than in the day samples during Days 2 and 3, whereas no day/night differences were detected from the other days, resulting in a significant interaction effect (ANOVA $; F=15.0 \mathrm{df}=3,16, \mathrm{p}<0.001$; SNK test, $\mathrm{p}<0.05$; Fig. $4 \mathrm{a}$ ). The number of shrimp on the $24 \mathrm{~h}$ ASS appeared lower than the sum of shrimp over $24 \mathrm{~h}$ on the $12 \mathrm{~h}$ ASS during Days 1 and 4, but no significant effect of immersion time was found, even though the $p$-value was suspiciously low ( $p=0.055$; Table 2 ). The number of shrimp on the $24 \mathrm{~h}$ ASS appeared to mirror the $12 \mathrm{~h}$ ASS immersed at night, and the difference between 12 and $24 \mathrm{~h}$ ASS over $24 \mathrm{~h}$ was larger when higher numbers of shrimp were found on the day immersion ASS (Fig. 4a,b). The sum of shrimp sampled on the 12 and $24 \mathrm{~h}$ ASS over $48 \mathrm{~h}$ was significantly higher for the second $48 \mathrm{~h}$ period than for the first

Table 1. Expt 1. Carcinus maenas. Number of shore crabs (megalopae and first instars) as a function of immersion time $(12$ and $24 \mathrm{~h}$ ) and date (August 8 to 12) over $24 \mathrm{~h}$ periods, and number of shore crabs (log-transformed) as a function of immersion time $(12,24$ and $48 \mathrm{~h}$ ) and date (August 8 to 12) over $48 \mathrm{~h}$ periods. Two-fixed-factor ANOVA models. ns: not significant

\begin{tabular}{|lrrrr|}
\hline Source of variation & SS & df & MS & $F$ \\
\hline $\mathbf{2 4} \mathbf{~ h}$ & & & & \\
Immersion time (A) & 4732 & 1 & 4732 & $27.5^{* * * *}$ \\
Date (B) & 6820 & 3 & 2273 & $13.1^{* * * *}$ \\
A $\times$ B & 726 & 3 & 242 & $1.4(\mathrm{~ns})$ \\
Error & 2778 & 16 & 174 & \\
$\mathbf{4 8 ~ h}$ & & & & \\
Immersion time (A) & 0.587 & 2 & 0.293 & $45.5^{* * * *}$ \\
Date (B) & 0.301 & 1 & 0.301 & $46.7^{* * * *}$ \\
A $\times$ B & 0.028 & 2 & 0.014 & $2.2(\mathrm{~ns})$ \\
Error & 0.077 & 12 & 0.006 & \\
${ }^{* * * *} \mathrm{p}<0.0001 ; \mathrm{ns} \mathrm{p}>0.05$ & & & \\
& & & & \\
\hline
\end{tabular}

Fig. 3. Expt 1. Carcinus maenas. Mean number of shore crabs (megalopae and first-instar crabs; $+\mathrm{SE}_{i} \mathrm{n}=3$ ) collected from artificial settlement substrates (ASS) immersed for different periods of time (12 to $96 \mathrm{~h}$ ). (a) ASS exposed for $12 \mathrm{~h}$ during the day (09:00 to 21:00 h); and the night $(21: 00$ to 09:00 h); (b) ASS exposed for $24 \mathrm{~h}$ and the sum of the concurrently fished $12 \mathrm{~h}$ ASS over $24 \mathrm{~h}_{\text {; }}$ (c) ASS exposed for $48 \mathrm{~h}$ and the sum of the concurrently fished 12 and $24 \mathrm{~h}$ ASS over $48 \mathrm{~h}$; (d) ASS exposed for $96 \mathrm{~h}$ and the sum of the concurrently fished 12, 24 and $48 \mathrm{~h}$ ASS over $96 \mathrm{~h}$. Shaded areas represent the proportion of first-instar crabs 


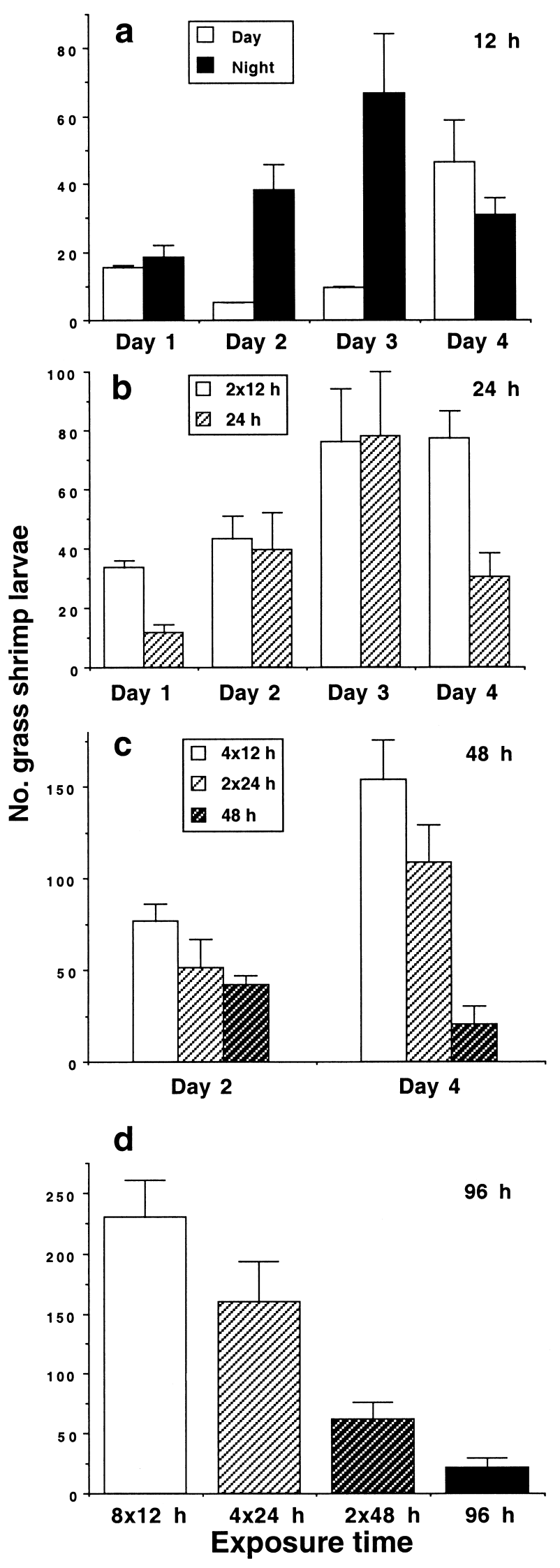

period. This difference was not found for the $48 \mathrm{~h}$ ASS, where the number of shrimp appeared to decrease during the second half (apparently reflecting the $12 \mathrm{~h}$ ASS night sample; Fig. 4a,c), causing a significant interaction effect (ANOVA: $F=6.0, \mathrm{df}=2,12, \mathrm{p}<0.05$; Fig. 4c). The 3 immersion times all differed significantly for the second period, whereas no differences were detected for the first period (SNK test, $\mathrm{p}<0.05$ ). The total number of shrimp over $96 \mathrm{~h}$ was significantly higher on the $12 \mathrm{~h}$ (230 shrimp) and $24 \mathrm{~h}$ ASS (160 shrimp) than for the 2 longer immersion times (48 h: 63 shrimp; 96 h: 22 shrimp), which did not differ significantly from each other (ANOVA: $F=15.7$, df $=$ $3,8, \mathrm{p}<0.001$; SNK test at $\mathrm{p}<0.05$; Fig. 4d).

\section{Expt 2. Benthic-pelagic migration trap-a pilot study}

The wind conditions during Expt 2 were variable, with on- and offshore winds between 1 and $14 \mathrm{~m} \mathrm{~s}^{-1}$ (Fig. 5a). The average tidal amplitude was $20 \mathrm{~cm}$, and an incoming high-pressure system caused a $40 \mathrm{~cm}$ drop in mean water level half way through the experiment (Fig. 5b). Current velocities measured at the opening of the bay at $1 \mathrm{~m}$ below the surface above $3 \mathrm{~m}$ depth varied between close to zero and $14 \mathrm{~cm} \mathrm{~s}^{-1}$ (Fig. 5c), and showed a relatively constant current direction, varying between 300 and $360^{\circ}$, and being parallel with the bay opening most of the time. Drift markers indicated that the surface current direction inside the bay reflected the wind direction at most times. No effect of the tides was seen in the current

Table 2. Expt 1. Palaemon spp. Number of grass shrimp larvae as a function of immersion time (12 and $24 \mathrm{~h})$ and date (August 8 to 12) over $24 \mathrm{~h}$ periods. Two-fixed-factor ANOVA model

\begin{tabular}{|lrrrr|}
\hline Source of variation & SS & df & MS & \multicolumn{1}{c|}{$F$} \\
\hline Immersion time (A) & 1882 & 1 & 1882 & $4.3(\mathrm{~ns})$ \\
Date (B) & 9428 & 3 & 3143 & $7.1^{* *}$ \\
$\mathrm{~A} \times \mathrm{B}$ & 2195 & 3 & 732 & $1.6(\mathrm{~ns})$ \\
Error & 7053 & 16 & 441 & \\
${ }^{* *} \mathrm{p}>0.01 ; \mathrm{ns} \mathrm{p}>0.05$ & & & & \\
\hline
\end{tabular}

Fig. 4. Expt 1. Palaemon spp. Mean number of grass shrimp larvae $\left(+\mathrm{SE}_{;} \mathrm{n}=3\right)$ collected from artificial settlement substrates (ASS) immersed for different periods of time (12 to $96 \mathrm{~h}$ ). (a) ASS exposed for $12 \mathrm{~h}$ during the day (09:00 to 21:00 h) and the night (21:00 to 09:00 h); (b) ASS exposed for $24 \mathrm{~h}$ and the sum of the concurrently fished $12 \mathrm{~h}$ ASS over $24 \mathrm{~h}$; (c) ASS exposed for $48 \mathrm{~h}$ and the sum of the concurrently fished 12 and $24 \mathrm{~h}$ ASS over $48 \mathrm{~h}$; (d) ASS exposed for $96 \mathrm{~h}$ and the sum of the concurrently fished 12, 24 and $48 \mathrm{~h}$ ASS over $96 \mathrm{~h}$ 
data (Fig. 5b,c). Temperature and salinity of the surface water varied between 15 and $17^{\circ} \mathrm{C}$, and 26 and $30 \mathrm{PSU}$, respectively.

The initial assessment of the MT in July showed that this new method could catch high numbers of both planktonic larvae and migrating juveniles under a variety of different wind and current conditions, and that the estimate of larval and juvenile fluxes had a high enough precision to detect temporal differences and significant net fluxes. A significant net in-flux of both shore crab megalopae (no first-instar crabs were found) and brown shrimp larvae and juveniles to the shallow area of the bay inside the traps were found during the $11 \mathrm{~d}$ period (Table 3, Fig. 5d,e). The abundance of both species showed significant variation between days, but with higher numbers in the MT-in than in the MT-out on all days (with the apparent exception of shore crabs on the last day: Fig. 5d,e). High numbers of shore crab megalopae were consistently collected in the MT-out, approximately $45 \%$ on average of the number coming in. In contrast, few brown shrimp ( $<4 \%$ on average) were collected in the MT that was fishing outgoing water. Immigrating brown shrimp consisted of an equal proportion of post-

Table 3. Expt 2. Carcinus maenas and Crangon crangon. Number of shore crab megalopae and brown shrimp [log $(x+1)$-transformed] as a function of migration-trap catch direction (in and out) and date (July 14 to 25). Two-fixedfactor ANOVA models

\begin{tabular}{|lrrrr|}
\hline Source of variation & SS & df & MS & $F$ \\
\hline Shore crab & & & & \\
Direction (A) & 1.75 & 1 & 1.75 & $14.4^{* * *}$ \\
Date (B) & 5.16 & 10 & 0.52 & $4.3^{* *}$ \\
A $\times$ B & 2.25 & 10 & 0.23 & $1.9(\mathrm{~ns})$ \\
Error & 2.67 & 22 & 0.12 & \\
Brown shrimp & & & & \\
Direction (A) & 15.48 & 1 & 15.48 & $258^{* * * *}$ \\
Date (B) & 1.89 & 10 & 0.19 & $3.1^{*}$ \\
A $\times$ B & 0.71 & 10 & 0.07 & $1.2(\mathrm{~ns})$ \\
Error & 1.32 & 22 & 0.06 & \\
${ }^{* * * *} \mathrm{p}<0.0001^{*}{ }^{* * *} \mathrm{p}<0.001 ;{ }^{* *} \mathrm{p}<0.01 ;{ }^{*} \mathrm{p}<0.05 ; \mathrm{ns} \mathrm{p}>0.05$ \\
\hline
\end{tabular}

Fig. 5. Expt 2. Physical and biological data from Bökevik from July 14 to 25, 1996. (a) Wind speed and direction (average over $3 \mathrm{~h}$ periods), bars follow the wind direction in relation to offshore (out; $32^{\circ}$ ) and onshore (in; $212^{\circ}$ ) of the bay; (b) water level (continuous measurements); (c) current velocity (averaged over $1 \mathrm{~h}$ periods) at $1 \mathrm{~m}$ depth at the opening of the bay above $3 \mathrm{~m}$ depth; (d) Carcinus maenas: mean number of shore crab megalopae $\left( \pm \mathrm{SE}_{;} \mathrm{n}=2\right)$ collected with benthic-pelagic migration traps (MTs) located inside the bay and facing offshore (MT-in) or onshore (MT-out) during $24 \mathrm{~h}$ periods; (e) Crangon crangon: mean number of brown shrimp (postlarvae and juveniles; $\pm \mathrm{SE}_{;} \mathrm{n}=2$ ) collected with the MT over $24 \mathrm{~h}$ periods larvae (i.e. 1.0 to $1.2 \mathrm{~mm} \mathrm{CL}$; Criales \& Anger 1986) and young juveniles (1.3 to $2.5 \mathrm{~mm} \mathrm{CL}$ ). The average size of the brown shrimp collected in the MT-in and MT-out were similar (1.3 and $1.5 \mathrm{~mm} \mathrm{CL}$, respectively).
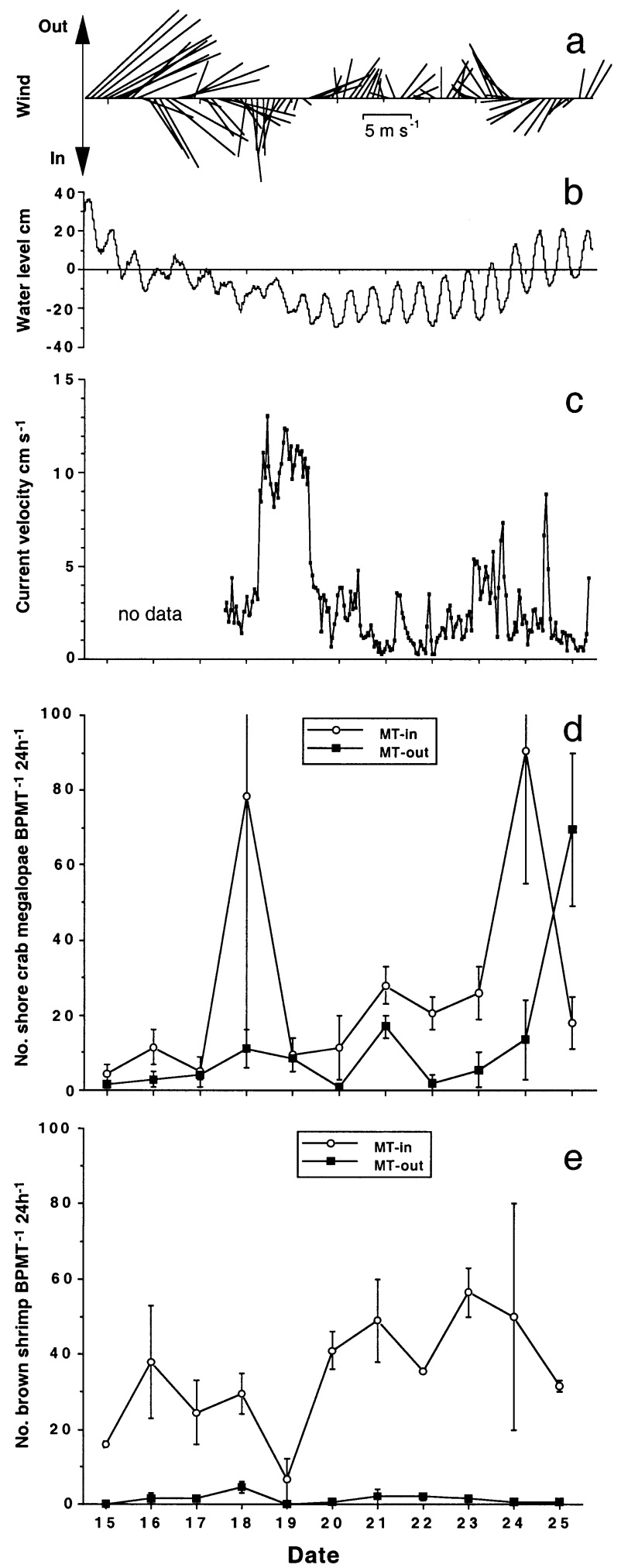

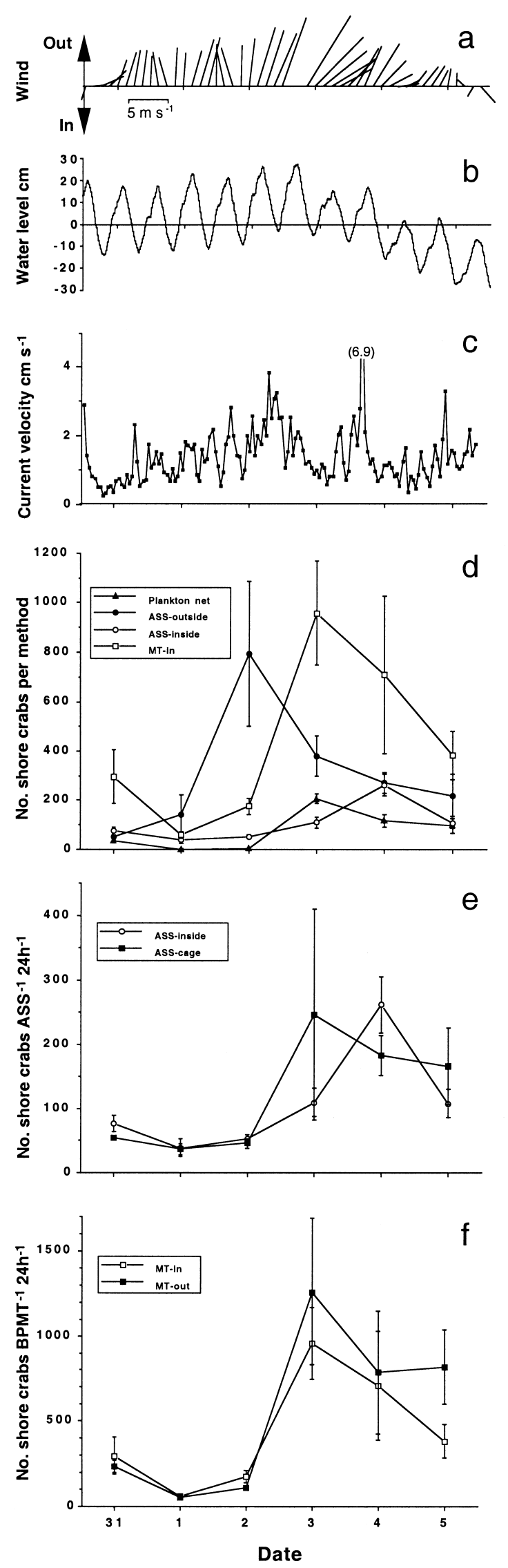

\section{Expt 3. Assessment of 3 different methods for esti- mates of decapod larval supply and settlement}

During Expt 3, a continuous offshore wind of variable strength (2 to $14 \mathrm{~m} \mathrm{~s}^{-1}$ ) was present (Fig. 6a). Average tidal amplitude was $29 \mathrm{~cm}$ during this period (Fig. 6b). Current measurements at $1 \mathrm{~m}$ below the surface above $3 \mathrm{~m}$ depth at the opening of the bay showed a relatively constant current velocity between 1 and $4 \mathrm{~cm} \mathrm{~s}^{-1}$ at most times (Fig. 6c), but a highly variable direction (between 150 and $360^{\circ}$ ), that did not reflect the relatively stable wind conditions. In contrast, the current direction at the surface inside the bay, measured with drift markers and passively floating markers, appeared to always follow the constant outward wind direction. The tidal changes were not reflected in the current data (Fig. 6b,c). Temperature and salinity in the surface water varied between 17 and $18^{\circ} \mathrm{C}$, and 24 and 25 PSU, respectively.

\section{Shore crab larval supply}

During the $6 \mathrm{~d}$ evaluation of different methods for estimates of larval supply, the bay experienced a peak in abundance of megalopae, and several methods produced strikingly different results (Fig. 6d). The number of shore crab collected from the ASS fished just outside the bay increased significantly during the first $3 \mathrm{~d}$ from 52 crabs (megalopae and first-instar crabs) $\mathrm{ASS}^{-1} 24 \mathrm{~h}^{-1}$ to a major peak of $793 \mathrm{crabs} \mathrm{ASS}^{-1} 24 \mathrm{~h}^{-1}$ on August 2 (ANOVA: $F=6.6, \mathrm{df}=5,12, \mathrm{p}<0.01$; SNK test, $\mathrm{p}<0.05$; Fig. 6d). During the same period the megalopae collected with the plankton net at the same location decreased to close to zero. The number of megalopae increased significantly in the plankton net tows during the last $3 \mathrm{~d}$ (up to 206 megalopae per tow; approximately 2 megalopae $\mathrm{m}^{-3}$; ANOVA: $F=50.0, \mathrm{df}=5,12$, $\mathrm{p}<0.0001$; SNK test, $\mathrm{p}<0.05$; Fig. 6d), when high numbers were still collected on the $\mathrm{ASS}_{\text {; }}$ however,

Fig. 6. Expt 3. Physical $(a, b)$ and shore crab (d, e, f) data from Bökevik from July 30 to August 5, 1996. (a) Wind speed and direction; (b) water level; (c) current velocity (see Fig. 5 legend for details of $\mathrm{a}, \mathrm{b}, \mathrm{c}$ ). (d) Mean number of Carcinus maenas (megalopae and first-instar crabs; $\pm \mathrm{SE}_{;} \mathrm{n}=3$ ) collected with 4 different methods: plankton net tows at the opening of the bay, artificial settlement substrates located at the opening of the bay (ASS-outside), ASS located inside the bay, and benthic-pelagic migration traps (MTs) located inside the bay and facing offshore (MT-in); (e) number collected with ASS located inside the bay at $0.6 \mathrm{~m}$ depth with or without predation-protective caging; (f) number collected with MTs located inside the bay facing offshore (MT-in) or onshore (MT-out). Note that data from ASS-inside and MT-in are shown in 2 different graphs for visual clarity 
Table 4. Expt 3. Carcinus maenas. Number of shore crab settlers $[\log (x+1)$-transformed] sampled with artificial settlement substrate (ASS) as a function of cage-treatment (cage, no cage) and date (July 30 to August 5), and numbers of settlers sampled with migration traps (MT) as a function of direction (in, out) and date. Two-fixed-factor ANOVA models

\begin{tabular}{|lrrrr|}
\hline Source of variation & SS & df & MS & $F$ \\
\hline ASS & & & & \\
Cage (A) & 0.001 & 1 & 0.001 & $0.001(\mathrm{~ns})$ \\
Date (B) & 2.71 & 5 & 0.54 & $9.7^{* * * *}$ \\
A $\times$ B & 0.31 & 5 & 0.01 & $0.50(\mathrm{~ns})$ \\
Error & 0.55 & 24 & 0.008 & \\
MT & & & & \\
Direction (A) & 0.012 & 1 & 0.012 & $0.24(\mathrm{~ns})$ \\
Date (B) & 6.62 & 5 & 1.33 & $27.2^{* * * *}$ \\
A $\times$ B & 0.23 & 5 & 0.05 & $0.94(\mathrm{~ns})$ \\
Error & 1.17 & 24 & 0.05 & \\
${ }_{* * * *} \mathrm{p}<0.0001 ; \mathrm{ns} \mathrm{p}>0.05$ & & & \\
& & & & \\
\hline
\end{tabular}

there was no correlation between the 2 methods (correlation analysis: $r=0.08, p=0.88$ ). Inside the bay, the number of megalopae on ASS was in general lower (39 to 262 crabs $\mathrm{ASS}^{-1} 24 \mathrm{~h}^{-1}$ ), and reached a significant peak 1 to $2 \mathrm{~d}$ after the peak on ASS outside the bay (Table 4; SNK test, $\mathrm{p}<0.05$; Fig. 6d), resulting in a poor correlation between ASS-outside and ASS-inside $(\mathrm{r}=$ $0.19, \mathrm{p}=0.71$ ). No significant difference was found between the ASS-inside and ASS-cages (Table 4), and there was a significant correlation between the 2 treatments ( $r=0.90, p=0.015$; Fig. 6e). High numbers of crabs were collected in the MTs (59 to 1260 crabs MT $^{-1}$ $24 \mathrm{~h}^{-1}$ ). with a significant peak during the last $3 \mathrm{~d}$, but no significant difference was found between the 2 directions on any date during this period (Table 4 ; SNK test, $p<0.05$; Fig. 6f), precluding estimates of net fluxes. The MT-in and ASS-inside correlated significantly over the $6 \mathrm{~d}(\mathrm{r}=0.84, \mathrm{p}=0.035)$.

\section{Shore crab developmental stage}

Both the proportion of first-instar crabs in the samples, and the metamorphosis rates of collected megalopae indicated that the different methods caught postlarvae of different development stages. The proportion of first-instar crabs was significantly higher in the MTin $(17 \%)$ than in the MT-out $(12 \%)$, which in turn were both significantly higher than the ASS methods (ASSoutside $=1.6 \%$, ASS-inside $=2.5 \%$, ASS-cage $=3.2 \%$ ); the ASS methods did not differ from each other (Fig. 7a, Table 5). Only 1 first-instar crab was found in the plankton tows. In the laboratory experiment, significant differences in time to metamorphosis (TTM) was found between the different methods (Table 5,
Fig. 7b). The megalopae collected in the plankton net tows showed significantly longer TTM (4.4 d) than all the other methods (Fig. 7b). Megalopae collected on ASS-outside showed significantly longer TTM (3.4 d) than ASS-inside $(2.5 \mathrm{~d})$. A trend towards longer TTM among megalopae from MT-out (3.0 d) compared to MT-in (2.6 d) could be seen (Fig. 7b), but was not significant (SNK test, $\mathrm{p}<0.05$ ).

\section{Shore crab settlement}

Settlement of shore crabs (megalopae and first-instar crabs) on natural blue mussel habitat in cages increased significantly from 112 crabs per mussel patch the first $48 \mathrm{~h}$ period to 354 crabs per mussel patch the
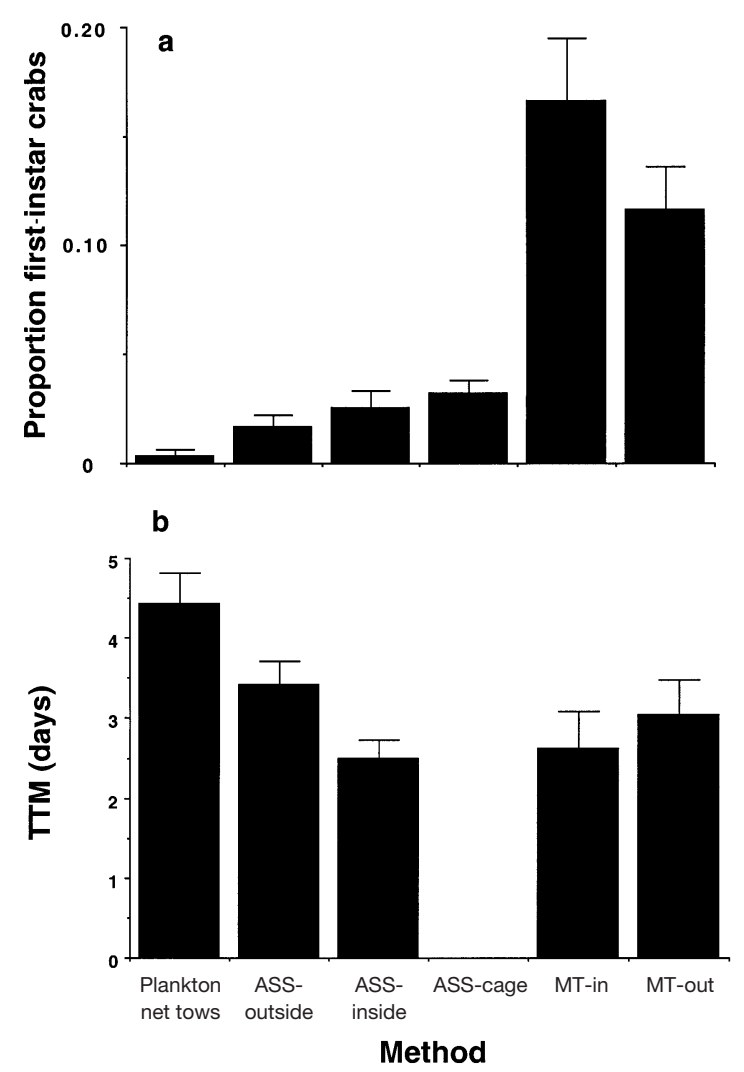

Fig. 7. Expt 3. Carcinus maenas. (a) Mean proportion of firstinstar shore crabs $\left(+\mathrm{SE}_{i} \mathrm{n}=3\right.$ ) collected with 6 different methods: plankton net tows at the opening of the bay, artificial settlement substrates located at the opening of the bay (ASS-outside), ASS located inside the bay, ASS located inside the bay with predation-protective caging, benthic pelagic migration traps located inside the bay and facing the opening (MT-in), and MT facing the back of the bay (MT-out) in Bökevik from July 30 to August 5, 1996 (data are pooled for the $6 \mathrm{~d}$ ); (b) mean time to metamorphosis (TTM; $+\mathrm{SE} ; \mathrm{n}=2$ ) for shore crab megalopae collected with 5 different methods in Bökevik July 30 to August 5 (TTM was not investigated for ASS-cage) 
Table 5. Expt 3. Carcinus maenas. Proportion of first-instar shore crabs (square-root-transformed) as a function of method (plankton net, ASS-outside, ASS-inside, ASS-cage, MTin and MT-out) and date (July 30 to August 5), and time to metamorphosis as a function of method (plankton net, ASS-outside, ASS-inside, MT-in and MT-out) and catch date (August 2 to 4). Two-fixed-factor ANOVA models

\begin{tabular}{|c|c|c|c|c|}
\hline Source of variation & SS & df & MS & $F$ \\
\hline \multicolumn{5}{|c|}{ Proportion 1st instars } \\
\hline Method (A) & 1.84 & 5 & 0.37 & $48.1^{* * * *}$ \\
\hline Date (B) & 0.24 & 5 & 0.05 & $6.4^{* *}$ \\
\hline $\mathrm{A} \times \mathrm{B}$ & 0.31 & 25 & 0.01 & $1.6(\mathrm{~ns})$ \\
\hline Error & 0.55 & 72 & 0.008 & \\
\hline \multicolumn{5}{|l|}{ Metamorphosis rate } \\
\hline Method (A) & 13.16 & 4 & 3.29 & $17.6^{* * * *}$ \\
\hline Date (B) & 5.78 & 2 & 2.89 & $15.6^{* * *}$ \\
\hline$A \times B$ & 3.22 & 8 & 0.40 & $2.2(\mathrm{~ns})$ \\
\hline Error & 2.55 & 14 & 0.18 & \\
\hline \multicolumn{5}{|c|}{${ }^{* * * *} \mathrm{p}<0.0001 ;{ }^{* * *} \mathrm{p}<0.001 ;{ }^{* *} \mathrm{p}<0.01 ;$ ns $\mathrm{p}>0.05$} \\
\hline
\end{tabular}

Table 6. Expt 3. Carcinus maenas. Sum of shore crabs $[\log (x+1)$-transformed] after $48 \mathrm{~h}$ as a function of method (cage, ASS-outside, ASS-inside, ASS-cage, MT-in) and period (July 30 to August 1, and August 1 to 3). Two-fixed-factor ANOVA model

\begin{tabular}{|lrrrr|}
\hline Source of variation & SS & df & MS & $F$ \\
\hline Method (A) & 1.50 & 3 & 0.50 & $11.4^{* * *}$ \\
Period (B) & 1.30 & 1 & 1.30 & $29.8^{* * * *}$ \\
$\mathrm{~A} \times \mathrm{B}$ & 0.37 & 3 & 0.12 & $2.8(\mathrm{~ns})$ \\
Error & 0.61 & 14 & 0.04 & \\
${ }^{* * * *} \mathrm{p}<0.0001 ;{ }^{* * *} \mathrm{p}<0.001 ; \mathrm{ns} \mathrm{p}>0.05$ & & \\
\hline
\end{tabular}

second $48 \mathrm{~h}$ period. The proportion of first-instar crabs collected in the cages was similar in the 2 periods, 20 and $18 \%$, respectively. A corresponding significant increase in larval supply was detected with all 4 methods assessed (Table 6, Fig. 8).

\section{Grass shrimps}

Similarly to the shore crab, the measurements of grass shrimp larvae showed strikingly different patterns between the locations inside and outside the bay, and different methods appeared to catch larvae at different development stages (Fig. 9a,b). High numbers of grass shrimp larvae were collected in plankton net tows, and showed a significant variation between days, with a major peak (217 shrimp tow ${ }^{-1}$ ) on the final day (ANOVA: $F=16.7, \mathrm{df}=5,12, \mathrm{p}<0.0001$; SNK test, $\mathrm{p}<$ $0.05)$. During the same period, the numbers on ASS- outside were relatively low (1 to 17 shrimp $\mathrm{ASS}^{-1}$ $24 \mathrm{~h}^{-1}$ ), and showed a significant increase the last $3 \mathrm{~d}$ (ANOVA: $F=4.5, \mathrm{df}=5,12, \mathrm{p}<0.05$; SNK test, $\mathrm{p}<$ $0.05)$, but no significant correlation with the plankton net tows $(r=0.64, p=0.17)$. Inside the bay the number of grass shrimp was low (MT-in: 3 to 9 shrimp $24 \mathrm{~h}^{-1}$; ASS-inside: 2 to 4 shrimp $24 \mathrm{~h}^{-1}$ ) and showed no significant differences between any dates or methods, nor any significant correlation between methods (all $\mathrm{p}>0.6)$.

The grass shrimp larvae consisted of both postlarvae and Larval Stage $V$, and the proportion of postlarvae varied significantly between methods (ANOVA: $F=$ 14.8, $\mathrm{df}=5,30, \mathrm{p}<0.0001$; Fig. 9b). A low proportion of postlarvae was collected in the plankton tows $(1 \%)$ which was similar to the proportion collected in the MT-out (12\%) but significantly lower than the proportion collected with all other methods (41 to $94 \%$ ). MTin collected a significantly higher proportion of postlarvae $(63 \%)$ than MT-out. A similar proportion of postlarvae was found on ASS-outside and ASS-inside (41 and $52 \%$, respectively), whereas a significantly higher proportion of postlarvae was found in the ASScage $(94 \%$; SNK test at $\mathrm{p}<0.01)$. No juvenile grass shrimp were collected with any method.

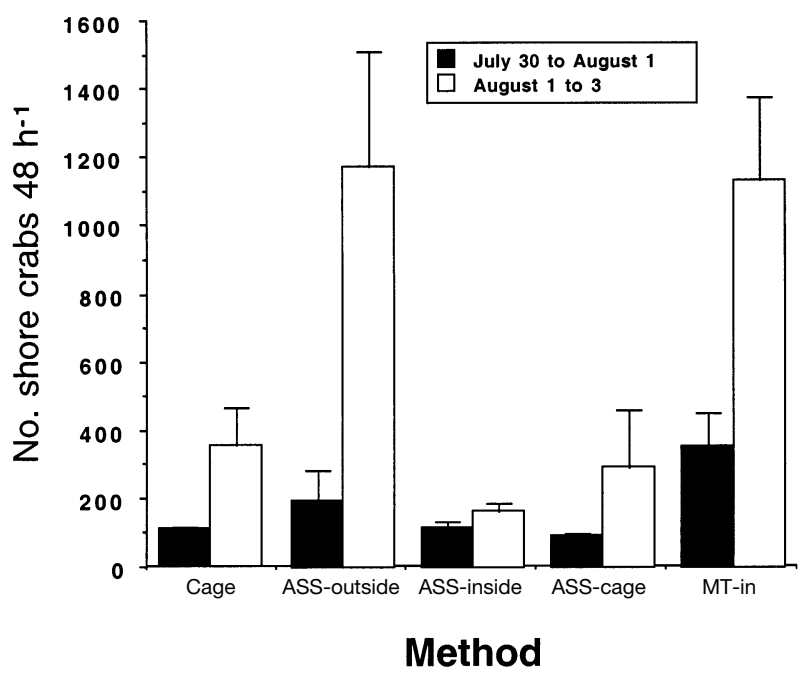

Fig. 8. Expt 3. Carcinus maenas. Mean number of shore crabs (megalopae and first-instar crabs; $+\mathrm{SE} ; \mathrm{n}=2$ or 3 ) collected in Bökevik during two $48 \mathrm{~h}$ periods with 5 different methods: natural blue mussel habitat provided with predation-protective caging (collected after $48 \mathrm{~h}$ ), artificial settlement substrates located at the opening of the bay (ASS-outside), ASS located inside the bay, ASS located inside the bay with predation-protective caging (ASS-cage), and benthic-pelagic migration traps located inside the bay and facing offshore (MT-in) 

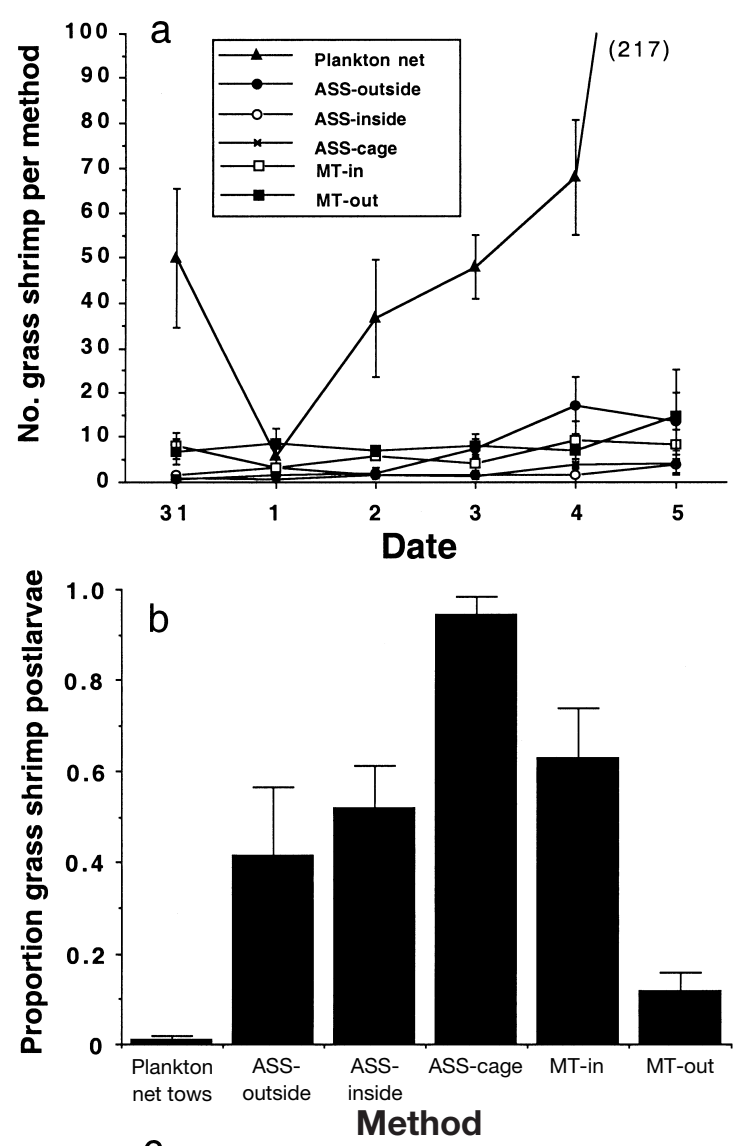

Brown shrimp

No brown shrimp Crangon crangon were collected with either plankton net tows or ASS, even though high numbers (up to 30 shrimp $\mathrm{MT}^{-1} 24 \mathrm{~h}^{-1}$ ) were collected in the MT-in. The number of brown shrimp collected in MT-in was significantly higher the first and the last $2 \mathrm{~d}$ compared to the other days and compared to MT-out, where numbers were always low (on average $14 \%$ of the number collected in MT-in), causing a significant interaction effect (ANOVA: $F=7.78, \mathrm{df}=$ 5,24, $\mathrm{p}<0.001$; SNK test, $\mathrm{p}<0.05$, Fig. 9c). Immigrating brown shrimp were dominated by young juveniles (1.3 to $3.0 \mathrm{~mm} \mathrm{CL})$, and few postlarvae $(<16 \%$ of the total number) were collected in the MTs. The average size of the brown shrimp collected in MT-in and MTout was similar (1.6 and $1.5 \mathrm{~mm} \mathrm{CL}$, respectively).

\section{DISCUSSION}

The main message emerging from these short experiments is that larval development stage and migratory behavior must be taken into account when designing a sampling method for the assessment of larval supply, settlement, and juvenile recruitment of decapod species. In the present study on Carcinus maenas, Crangon crangon and Palaemon spp., different sampling methods collected different development stages of the assessed species and produced strikingly different temporal patterns in larval abundance. Discrete plankton net tows produced a snapshot of the water-column abundance of larvae, and collected a high proportion of larvae not competent to settle that, in turn, poorly represented the average larval supply and settlement in the assessed nursery area. Artificial settlement substrates gave a good integrated relative estimate of larval abundance and settlement densities for shore crabs, but high losses over time from the ASS, probably due to postlarval emigration, made this method less suitable for grass shrimp. Benthic pelagic migration traps gave promising integrated estimates of both larval and juvenile fluxes to a shallow nursery area, and showed that the recruitment of brown shrimp occurred mainly through juvenile migration. This method also demonstrated high emigration rates of shore crab and grass shrimp larvae from the assessed bay that were related to larval development stage, indicating that many decapod postlarvae found in nursery areas may be transitional.

\section{Plankton net tows}

Discrete daytime surface plankton tows outside the bay appeared to be of limited value for estimating lar- 
val supply and settlement for the investigated species due to a patchy distribution of larvae, unpredictable currents regimes, and the presence of larvae not ready to settle in the water-column. Larval supply of shore crab megalopae was highly variable (>10-fold difference in abundance between days, as estimated with both the MT and the ASS) and did not correlate to the generally constant flow-velocity (1 to $4 \mathrm{~cm} \mathrm{~s}^{-1}$ ) during Expt 3, suggesting a patchy distribution of the planktonic megalopae. Larval patchyness produces a high temporal variation in larval water-column abundance and poses a severe problem for methods that involve discrete sampling. In this study, the continuously fishing ASS-outside showed a peak of megalopal abundance that was not found in the discrete plankton net samples for several days, and no correlation was found between larval abundance estimated by the 2 methods. The problem of high temporal variation in larval abundance may have been accentuated by the unpredictable current regimes in this microtidal area. The lack of correlation between current velocities and tidal amplitude makes it difficult to determine when to sample, and calls for very frequent or continuous sampling if this method is to be used successfully. Limitations with discrete plankton net tows have also been demonstrated in tidal areas for estimating larval supply of intertidal barnacles (Gaines \& Bertness 1993). Furthermore, analysis of the metamorphosis rate of the sampled shore crab postlarvae demonstrated that megalopae collected with plankton nets outside the bay were in an earlier development stage than the megalopae collected with the other methods. Similarly, grass shrimp larvae collected with plankton tows consisted almost entirely of Stage V larvae, and correlated poorly with the number collected on the ASS and to larvae entering the bay, which were dominated by the postlarval stage. Thus, the water-column abundance of larvae estimated with discrete plankton tows may not reflect settlement densities since all larvae may not be competent to settle. Our results are consistent with studies on blue crabs in which megalopae collected with plankton nets showed an earlier development stage than megalopae collected with ASS (Lipcius et al. 1990), and a poor correlation in abundance between the 2 methods (Olmi et al. 1990). Finally, daytime surface plankton net tows were unsuccessful in collecting brown shrimp larvae and juveniles, even though high numbers were concurrently collected with the MT inside the bay, suggesting that this is an improper method to estimate larval supply for this species. However, one caveat to these conclusions is that only daytime plankton net samples were assessed in this study. Additional studies also assessing nighttime plankton tow samples in relation to the other methods are warranted. Further, for species that show no association to structurally complex habitats and that appear to avoid entering MTs, such as plaice larvae Pleuronectes platessa (H.W. unpubl. data), plankton net tows may be the best collection method available.

\section{Artificial settlement substrates-temporary 'settlement'}

\section{Shore crabs}

High losses of shore crab settlers were found on ASS that were immersed longer than $12 \mathrm{~h}$, and the losses increased with increasing immersion time. Since the similar abundance of settlers collected on ASS provided with and without protective cages in Expt 3 indicate that predation was low on the ASS, these losses were most likely caused by emigration of postlarvae. Emigration by juvenile crabs is a less likely explanation for the loss, since benthic first-instar stages of shore crabs cannot swim and the ASS were suspended $3 \mathrm{~m}$ above the bottom. The metamorphosed megalopae might therefore become 'stranded' on the ASS, as indicated by the increasing proportion of first-instar crabs collected during the longer immersion times. This result suggests that most postlarvae 'settle' only temporarily on the ASS, and that the emigration rate is not constant but involves a delay of less than $24 \mathrm{~h}$, after which a large proportion of the megalopae leaves the substrate. The number of shore crabs on the $24 \mathrm{~h}$ ASS reflected the number of crabs on the $12 \mathrm{~h}$ night ASS better than on the $12 \mathrm{~h}$ day ASS, suggesting that most megalopae that 'settled' during the day emigrated during the night. This is supported by a recent laboratory study, in which shore crab megalopae showed diurnal swimming behavior and emigrated from habitats at night (P.-O.M. unpubl. data). The lack of a constant difference between day and night may be explained by intense settlement during the $5 \mathrm{~h}$ of light in the morning before the night immersion was sampled. In an attempt to estimate the daily emigration rate from the ASS in the study, we fitted our data to a simple model that estimates the sum of settlers after $96 \mathrm{~h}$ for the different immersion times used:

$$
N_{96}=[I \times(96 / I T)]+[I \times(1-E)] \times[8-(96 / I T)]
$$

where $N_{96}=$ the sum of settlers after $96 \mathrm{~h}, I=$ total immigration to the ASS $12 \mathrm{~h}^{-1}, I T=$ immersion time (h) and $E=$ the proportional emigration occurring at night. This model assumes that a constant proportion of the megalopae that settled during the day emigrated only during their first night on the ASS. Employing a least-squares analysis and using an immigration rate of 30 (mean number of settlers on $12 \mathrm{~h}$ ASS), our data suggest that $83 \%$ of the megalopae left the ASS during the night. Thus, for 
shore crabs, it is inappropriate to refer to the transitional megalopae on ASS as 'settled', since this term refers to the termination of a pelagic larval phase and assumption of a benthic life (Scheltema 1974), often associated with metamorphosis. Instead, for this species, ASS appear to give a relative estimate of planktonic larval abundance of megalopae in a late development stage.

Because the emigration rate from the ASS was fairly constant between days during this short experiment, an increase in larval supply over the $4 \mathrm{~d}$ period, found on the $12 \mathrm{~h}$ ASS, was detected also with the 24 and $48 \mathrm{~h}$ ASS. Thus, despite the high emigration rate, both 24 and $48 \mathrm{~h}$ ASS appeared to yield useful relative estimates of megalopal larval supply in this study. This was supported in Expt 3 in which the number of shore crabs collected on $24 \mathrm{~h}$ ASS inside the bay correlated significantly with the larval supply estimated by the MT-in, and reflected settlement densities found in the caged blue mussel habitat. A similar positive correlation between larval numbers on ASS, in plankton nets and in caged natural habitats have been found for Dungeness crabs on the US west coast where the arrival of larvae was highly predictable (Eggleston \& Armstrong 1995). For estimates of larval supply of shore crabs in microtidal areas, we recommend that the ASS are fished for a maximum of $24 \mathrm{~h}$ and collected in the afternoon/ evening, since megalopae appear to emigrate at dusk (P.-O.M. unpubl. data), to minimize potential confounding effects of the megalopal emigration.

In summary, the ASS appear to produce good integrated relative estimates of shore crab larval supply, and possibly also of initial settlement densities. Since the migration traps showed that recruitment of juvenile shore crabs to the assessed nursery area occurred almost entirely through planktonic megalopae, the estimate of settlement should be useful for recruitment studies of this species. However, the high proportion of transitional megalopae, indicated in this study, warrants further studies on how these estimates correlate with settlement densities in natural habitats. We urge colleagues using this technique with other decapod species to assess the proportion of transitional postlarvae on the ASS, and to assess how emigration rates from the collectors are affected by physical and biological factors. Such information would allow for the optimization of immersion and collection time, while assuring that estimates of larval abundance and settlement are not confounded by larval emigration.

\section{Grass shrimp}

Similar to the shore crabs, an increased immersion time resulted in an increasing loss of shrimp from the ASS. The number of shrimp found on both 24,48 and
$96 \mathrm{~h}$ ASS was very similar to the number found on the $12 \mathrm{~h}$ ASS fished during the last night of the longer immersion times. Consequently, the number of larvae that 'settled' the day or days before was not reflected in the longer immersion times. Hence, the association to the ASS seems to be completely temporary, and after a delay of $<24 \mathrm{~h}$, all shrimp appear to leave the ASS. Thus, ASS used for periods $>12 \mathrm{~h}$ do not yield a useful integrated estimate of grass shrimp larval supply. In contrast to juvenile shore crabs, grass shrimp postlarvae and juveniles are competent swimmers that can easily migrate from the artificial substrate to more optimal habitats close by, which might explain why the ASS method produced poorer results for grass shrimp than for shore crabs.

\section{Benthic-pelagic migration trap}

The new method using passive plankton net traps showed promising results in obtaining integrated migration estimates for both pelagic postlarvae and newly settled juvenile crabs and shrimp in shallow nursery areas. In comparison to plankton net tows and ASS, this method demonstrated several potential advantages: (1) It fished continuously and was therefore little affected by temporal variation in larval supply or current velocities. (2) It prevented escape and thus was not affected by variation in emigration rates. (3) It fished both plankton and animals moving on the sediment and could therefore also measure recruitment by migrating juveniles. (4) It fished in a directional manner, a known percentage of the water column at the opening of a bay, and could therefore potentially estimate the total net flux (number immigrating - number emigrating per unit time) of larvae and juveniles to a nursery area for the assessment of juvenile recruitment. Potential disadvantages with this technique are behavioral avoidance of the traps, clogging of traps by drifting macroalgae, and risk of predation inside the traps. In the present study, no drift algae were present in the water and predation on settlers inside the traps appeared to be limited since the juvenile crabs, shrimps and fishes found inside the MTs were too small $(<4 \mathrm{~mm}$ carapace width and length, and $15 \mathrm{~mm}$ total length, respectively) to be efficient predators on crab and shrimp recruits (Moksnes et al. 1998, P.-O.M. unpubl. data). The pattern of net fluxes and the role of juvenile migration for the recruitment were notably different for the 3 species investigated.

\section{Shore crabs}

The MT appeared useful in obtaining integrated estimates of both shore crab larval supply and juvenile 
migration to a shallow nursery area. The number of settlers collected on MT-in correlated significantly with the abundance of settlers on ASS located inside the bay, and reflected changes in shore crab settlement-densities in caged mussel habitats. However, the results concerning net fluxes were less clear. During the first assessment of the MT, a significant net in-flux was detected daily over an $11 \mathrm{~d}$ period, even though emigration rates (estimated by MT-out) were high (on average, $45 \%$ of the number collected in MT-in). The second assessment occurred during a major peak in larval supply of shore crabs, and no significant difference was found between numbers of shore crabs collected with MT-in and MT-out. This result indicates very high emigration rates of megalopae, and that netrecruitment of juveniles was too small to be detected. However, the high numbers of first-instar crabs found in the caged blue mussel habitats indicate that high numbers of megalopae had settled in the bay during the study period. These conflicting results suggest that the settlement observed might only constitute a small fraction of the megalopae that passed through the bay, hidden from detection in the MT-data because of the large variance in larval abundance during the high settlement peak. It is also possible that emigration was unusually high during Expt 3 due to strong winds that continuously blew out of the bay during this period.

Occasional sampling of the arms of the MTs during Expt 3 showed that high numbers of shore crab megalopae were clinging to the $800 \mu \mathrm{m}$ net (the number of megalopae found inside the arms, which was not included in the analysis, constituted approximately $24 \%$ of the number in the trap on average). Thus, for this species, the MT appeared not to fish with $100 \%$ efficiency over the $2 \mathrm{~m}$ opening between the arms, and we suggest that the MT be used without arms for better estimates of shore crab megalopae fluxes in future studies.

The significantly higher proportion of first-instar crabs found in the MTs compared to the other methods appears not to have been caused by higher metamorphosis rates among megalopae collected with MTs, since this was not indicated in the analysis of metamorphosis rates. The results indicate that high numbers of first instars entered the MTs (an estimated 40 crabs on average, constituting approximately $10 \%$ of the total number). The MT-in showed a significantly higher proportion of first instars than that collected with the MTout. This indicates that a small percentage $(<10 \%)$ of the juvenile recruitment occurred through first instars migrating in from deeper water, or that megalopae entering the bay had a higher metamorphosis rate, as indicated by the metamorphosis rate analysis.

The high postlarval emigration rates suggested by the results from both the ASS and the MT were unexpected, and indicate that most shore crab mega- lopae were only transitional in the nursery areas, even though they were close to metamorphosis. These results contrast with the suggestion that planktonic postlarvae settle and metamorphose into the first shelter they encounter because of high mortality rates in the plankton (Bell \& Westoby 1986), and warrant more studies of the proximate and ultimate causes of this emigration behavior. If a significant proportion of the assumed settled postlarvae sampled in nursery areas is only transitional, it could confound estimates of postsettlement mortality.

\section{Grass shrimp}

Larvae of the grass shrimps were only collected with the MT during Expt 3, when low numbers of Larval Stage $\mathrm{V}$ and postlarvae entered the bay. No significant correlation was found between the number of larvae caught by the MT and the other methods, probably in part due to the low number of shrimp collected, making the evaluation of the MT-method for this species difficult. Similar to the shore crab, a high proportion of emigration was found at all times, as indicated by similar numbers of larvae collected by MT-in and MT-out. However, the proportion of postlarvae was significantly higher in MT-in (63\%) than in the MT that fished outgoing water (12\%), which was dominated by Larval Stage V. This result suggests that settlement occurs during the postlarval stage, and that larvae in Stage $\mathrm{V}$ found in nursery areas and on ASS are only transitional. No juvenile grass shrimp were found in any samples, indicating that juvenile migration played a minor role in recruitment during this period.

\section{Brown shrimp}

The MT was the only method that successfully collected brown shrimp. In contrast to shore crabs and grass shrimp, brown shrimp showed very low rates of emigration at all times, resulting in a significant net influx on most dates. A large proportion of the brown shrimp collected in the MT-in (52 and $84 \%$ on average in Expts 2 and 3, respectively) consisted of young juveniles (1.3 to $3.0 \mathrm{~mm} \mathrm{CL}$ ), suggesting that juvenile recruitment to this shallow nursery area comprised mainly migrating juveniles that had settled outside the bay. This result demonstrates that juvenile migration must be incorporated in studies assessing recruitment regulation of motile species. Thus, MT appears to be a good method for quantitative estimates of recruitment for brown shrimp in shallow microtidal areas, and further studies with passive migration traps for this species are encouraged. 
Acknowledgements. We thank Jacques van Montfrans for introducing us to the method of using artificial settlement substrates and generously providing us with 'hogs hair' airconditioning filter material, Christopher Roberts and Anders Svenson for excellent assistance during the field experiments, Elsina Flach for letting us borrow her cages, the staff at Kristineberg Marine Research Station for providing excellent facilities, and Bengt Liljeblad, Leif Pihl, Henrique Queiroga, Peter Tiselius and 3 anonymous referees for helpful comments on the manuscript. This research was made possible through grants from the Swedish Council for Forestry and Agricultural Research (SFAR) and the World Wide Fund For Nature (WWF), 'Kungliga och Hvitfeldska överskottsfonden' and 'Hierta-Retzius stipendiefond' from the Royal Swedish Academy of Sciences, all of which are kindly acknowledged.

\section{LITERATURE CITED}

Andersson L, Rahm L (1985) Heat balance of a shallow cove. Estuar Coast Shelf Sci 23:705-724

Bell JD, Westoby M (1986) Variation in seagrass height and density over a wide spatial scale: effects on common fish and decapods. J Exp Mar Biol Ecol 104:275-296

Beniger PG, Chiasson L, Elner, RW (1986) The utility of artificial collectors as a technique to study benthic settlement and early juvenile growth of the rock crab, Cancer irrotatus. Fish Res 4:317-329

Blau SF, Byersdorfer SC (1994) Sausage-shaped artificial collector developed in Alaska to study young-of-year red king crabs. Bull Mar Sci 55:878-886

Caley MJ, Carr MH, Hixon MA, Hughes TP, Jones GP, Menge BA (1996) Recruitment and the local dynamics of open marine populations. Annu Rev Ecol Syst 27:477-500

Criales MM, Anger K (1986) Experimental studies on the larval development of shrimps Crangon crangon and C. allmani. Helgol Meeresunters 40:241-266

Eggleston DB, Armstrong DA (1995) Pre- and post-settlement determinants of estuarine Dungeness crab recruitment. Ecol Monogr 65:193-216

Gaines SD, Bertness M (1993) The dynamics of juvenile dispersal: why field ecologists must integrate. Ecology 74 : $2430-2435$

Goodrich DM, van Montfrans J, Orth RJ (1989) Blue crab megalopal influx to Chesapeake Bay (Virginia, USA): evidence for a wind-driven mechanism. Estuar Coast Shelf Sci 29:247-260

Hedvall O, Moksnes PO, Pihl L (1998) Active habitat selection by megalopae and juvenile shore crabs Carcinus maenas: a laboratory study in an annular flume. Hydrobiologia 375/376:89-100

Editorial responsibility: Kenneth Heck (Contributing Editor), Dauphin Island, Alabama, USA
Höglund H (1943) On the biology and larval development of Leander squilla (L.) forma typica de Man. Sven HydrogrBiol Kommn Skr 2(6)1-44

Lipcius RN, Olmi III EJ, van Montfrans J (1990) Planktonic availability, molt stage and settlement of blue crab postlarvae. Mar Ecol Prog Ser 58:235-242

Miron G, Boudreau B, Bourget E (1995) Use of larval supply in benthic ecology: testing correlations between larval supply and larval settlement. Mar Ecol Prog Ser 124: 301-305

Moksnes PO, Pihl L, van Montfrans J (1998) Predation on postlarvae and juveniles of the shore crab Carcinus maenas: importance of shelter, size and cannibalism. Mar Ecol Prog Ser 166:211-225

Olmi EJ, van Montfrans J, Lipcius RN, Orth RJ, Sadler PW (1990) Variation in planktonic availability and settlement of blue crab megalopae in the York River, Virginia. Bull Mar Sci 46:230-243

Palmer MA, Allan D, Butman CA (1996) Dispersal as a regional process affecting the local dynamics of marine and stream benthic invertebrates. Trends Ecol Evol 11: 322-326

Phillips BF (1972) A semi-quantitative collector of puerulus larvae of the western rock lobster Panulirus longipes cygnus George (Decapoda, Palinuridea). Crustaceana 22: $147-157$

Scheltema RS (1974) Biological interactions determining larval settlement of marine invertebrates. Thalassia Jugosl 10:263-296

Shanks AL (1983) Surface slicks associated with tidally forced internal waves may transport pelagic larvae of benthic invertebrates and fishes shoreward. Mar Ecol Prog Ser 13: 311-315

Sokal RR, Rohlf FJ (1981) Biometry. The principles and practice of statistics in biological research, 2nd edn. W. H. Freeman \& Co., New York

Söderkvist J (1997) Water exchange in a shallow bay. Master thesis. Department of Oceanography, Göteborg University, Sweden

Underwood AJ (1981) Techniques of analysis of variance in experimental marine biology and ecology. Oceanogr Mar Biol Annu Rev 19:513-605

van Montfrans J, Peery CA, Orth RJ (1990) Daily, monthly and annual settlement patterns by Callinectes sapidus and Neopanope sayi megalopae on artificial collectors deployed in York River, Virginia 1985-1988. Bull Mar Sci 46: 214-229

van Montfrans J, Epifanio CE, Knott DM, Lipcius RN, Mense DJ, Metcalf KS, Olmi EJ, Orth RJ, Posey MH, Wenner EL, West TL (1995) Settlement of blue crab postlarvae in Western Atlantic estuaries. Bull Mar Sci 57:834-854

Submitted: October 14, 1998; Accepted: June 23, 2000

Proofs received from author(s): November 21, 2000 